\title{
Levels of feed supplementation on the qualitative aspects of meat from crossbred goats finished on caatinga ${ }^{1}$
}

\author{
Níveis de suplementação alimentar sobre as características qualitativas carne de \\ caprinos mestiços terminados na caatinga
}

\author{
Daniel Cézar da Silva ${ }^{2 *}$, Adriana Guim³, Gladston Rafael de Arruda Santos ${ }^{4}$, Maria Inês Sucupira Maciel $^{5}$ e \\ Luciana Felizardo Pereira Soares ${ }^{3}$
}

\begin{abstract}
The effect was evaluated of feed supplementation $(0.0,0.4,0.8$, and $1.2 \%$ of body weight) on the qualitative aspects of goat meat (moisture, ash, fat, protein, colouring using the CIE ( $\mathrm{L}^{*}, \mathrm{a}^{*}$ and $\mathrm{b} *$ ) system, $\mathrm{pH}$, cooking loss and shear force), and also on the sensory attributes of goat aroma, off-aroma, colour, texture, tenderness, flavour, off-flavour, juiciness and overall appearance. A total of 32 crossbred Anglo-Nubian goats were used, organised into randomised blocks and finished on a pasture of caatinga. There was a quadratic effect $(\mathrm{p}<0.05)$ on the levels of ash and protein, with a maximum of 1.06 and $20.44 \mathrm{~g} / 100 \mathrm{~g}$ respectively. A positive linear affect $(\mathrm{p}<0.05)$ was seen on fat levels, with an increase of 0.52 $\mathrm{g} / 100 \mathrm{~g}$. There was a negative linear effect $(\mathrm{p}<0.05)$ on the qualitative parameters of cooking loss, shear force and $\mathrm{L}^{*}$, with decreases of $3.32 \%, 0.77 \mathrm{kgf} / \mathrm{cm}^{2}$ and 3.39 respectively, and a quadratic effect $(\mathrm{p}<0.05)$ on $\mathrm{a}^{*}$, with a maximum of 9.13. There was a quadratic effect $(\mathrm{p}<0.05)$ on the parameter $\mathrm{b}^{*}$, with a maximum of 8.12 , while the $\mathrm{pH}$ was not affected, with an average of 5.57. The sensory attributes were not influenced ( $p>0.05)$ by feed supplementation, except for colour and general appearance. Feed supplementation at $0.8 \%$ of body weight provides an increase in ash, fat and protein levels associated with qualitative improvements in cooking loss, tenderness and colouring, with increases in the sensory attributes of colour and overall appearance.
\end{abstract}

Key words: Meat colouring. Feeding strategy. Native pasture. Flavour. Tenderness.

RESUMO - Avaliou-se o efeito da suplementação alimentar (0;0,4;0,8 e 1,2\% do peso corporal) sobre os aspectos qualitativos da carne caprina (umidade, cinzas, gordura, proteína, coloração da carne pelo sistema CIE (L*, a* e b*), pH, perda por cocção e força de cisalhamento) e atributos sensoriais aroma caprino, aroma estranho, cor, textura, maciez, sabor caprino, sabor estranho, suculência e aparência geral. Utilizou-se 32 caprinos mestiços da raça Anglonubiana que foram distribuídos segundo delineamento em blocos casualizados, sendo terminados pastagem de caatinga. Houve efeito quadrático $(\mathrm{p}<0,05)$ para os teores de cinza e proteína, com máxima de 1,06 e 20,44 g/100 g, respectivamente. Verificou-se efeito linear positivo ( $\mathrm{p}<0,05)$ sobre o teor de gordura, com incremento de $0,52 \mathrm{~g} / 100 \mathrm{~g}$. Os parâmetros qualitativos foram influenciados ( $\mathrm{p}<0,05)$, com efeito linear negativo $(p<0,05)$ sobre a perda por cocção, força de cisalhamento e $\mathrm{L}^{*}$, com decréscimos de $3,32 \% ; 0,77 \mathrm{kgf} / \mathrm{cm}^{2} \mathrm{e}$ 3,39 , respectivamente, e efeito quadrático $(\mathrm{p}<0,05)$ para a*, com máxima de 9,13 . O parâmetro $\mathrm{b}^{*}$ apresentou efeito quadrático ( $\mathrm{p}<0,05)$, com máxima 8,12 , ao contrário do $\mathrm{pH}$ que não foi influenciado, com média 5,57. Os atributos sensoriais não foram influenciados $(\mathrm{p}>0,05)$ pela suplementação alimentar, com exceção da cor e aparência geral. A suplementação alimentar com 0,8\% do peso corporal propicia elevação nos teores de cinza, gordura e proteína, associados a melhoras qualitativas sobre a perda por cocção, maciez e coloração, com incrementos dos atributos sensoriais de cor e aparência geral.

Palavras-chave: Coloração da carne. Estratégia alimentar. Maciez. Pasto native. Sabor.

\footnotetext{
DOI: $10.5935 / 1806-6690.20150074$

* Autor para correspondência

${ }^{1}$ Recebido para publicação em 18/01/2014; aprovado em 13/06/2015

Parte da Tese de Doutorado do primeiro autor, financiada pela FACEPE e executada pelo acordo UFRPE/Instituto Agronômico de Pernambuco-IPA

${ }^{2}$ Instituto Federal de Educação, Ciência e Tecnologia da Paraíba/IFPB, Campus Sousa, Rua Presidente Tancredo Neves, Jardim Sorrilândia, s/n, Sousa-PB, Brasil, CEP 58.800-970, danielcezar.s@ig.com.br

${ }^{3}$ Departamento de Zootecnia, Universidade Federal Rural de Pernambuco/UFRPE, Recife-PE, Brasil, aguim@dz.ufrpe.br, lfpmendes_82@hotmail.com ${ }^{4}$ Departamento de Zootecnia, Universidade Federal de Sergipe/ UFS, Aracaju-SE, Brasil, gladstonrafael@ufs.br

${ }_{5}^{5}$ Departamento de Ciências Domésticas, Universidade Federal Rural de Pernambuco/UFRPE, Recife-PE, Brasil, m.ines@ dcd.ufrpe.br
} 


\section{INTRODUCTION}

Goat farming is of crucial importance to the economy of the north-eastern region of Brazil, where the population of these animals is estimated at around 8.5 million head, corresponding to $91 \%$ of the total for the country (IBGE 2011). Mainly concentrated in the arid and semi-arid regions, they play an important social, economic and nutritional role for small farmers.

Despite this importance, goat products have gone beyond rural barriers, no longer being considered a subsistence product of the northeast of the country, with demand currently increasing in large urban centres, and greater value being afforded these products due to the use of marketing strategies.

Even with this economic bias, the quality aspects of goat meat from the northeast still fall short of the actual needs of the demanding consumer market. This is because the meat comes from older, leaner animals, of small size; a fact that can be attributed to such failures in feeding management as the overuse of pasture, its carrying capacity and deficiencies in vitamin and mineral supplements, and in energy and/or protein supplements.

The commercial value of the meat is further influenced by its degree of acceptability, which is directly related to its chemical composition and sensory parameters. (MADRUGA et al., 2005). In addition, according to Santos Filho et al. (2005), healthy food is currently sought after by a significant part of the population interested in preventing metabolic disorders, a fact that guides research into evaluating and classifying various food types according to the needs of consumers.

Given the above scenario, it is necessary to evaluate the genetic groups that are predominant in the northeast, such as the crossbreed. Together with the breed, it is also necessary to evaluate the effect of nutritional management, especially of feed supplements, on meat quality, in order to offer practical and easy alternatives. According to Andrade et al. (2010), the use of feed supplements is a necessary strategy in production systems of the northeast, and can take the form of both inorganic and energy and/or protein supplements.

For Paulino et al. (2008), the use of this nutritional strategy at times of rainfall shortage is important for benefit to be gained from the entire diet, especially on a pasture of native caatinga, focusing mainly on compensating for the shortage of potentially digestible dry matter, together with correcting for limiting nutrients.

In addition to contributing nutrients, feed supplementation may be associated with providing additional sources of roughage, complementing that consumed by animals grazing on a pasture of caatinga, as for example, the use of native xerophilic roughage.

Despite the positive aspects of rational feed supplementation, such nutritional management is rarely used in the northeast, especially for goats. It has therefore become necessary to undertake studies to evaluate responses to this practice in goats finished on a pasture containing a variety of vegetation, such as caatinga.

The aim of this research was to evaluate the effect of feed supplementation on the qualitative and sensory characteristics of meat from crossbred goats finished on a pasture of caatinga.

\section{MATERIAL AND METHODS}

The research was carried out from August to December of 2009 at the Sertânia Experimental Station of the Pernambuco Institute of Agronomy (IPA), located at $08^{\circ} 04^{\prime} 25^{\prime \prime} \mathrm{S}$ and $37^{\circ} 15^{\prime} 52^{\prime}$ ' $\mathrm{W}$, in the micro-region of Sertão do Moxotó, in the state of Pernambuco, Brazil. The ecosystem is of caatinga and the climate is type BShW, semi-arid, having distinct wet and dry seasons. The mean temperature for the evaluation period was $25.1^{\circ} \mathrm{C}$ with an accumulated rainfall of 71.05 (LAMEPE, 2011).

The effect was evaluated of different levels of protein-energy feed supplementation, based on dry matter, at $0.0,0.4,0.8$, and $1.2 \%$ of body weight $(\% \mathrm{BW})$, on the qualitative and sensory characteristics of the meat from crossbred goats finished on a pasture of caatinga.

The feed supplement consisted of Nopalea cochenillifera (L.) SD, known locally as palma miúda, processed in a cactus grinding machine, concentrated and formulated according to the nutritional requirements recommended by NRC (2007) to meet a minimum daily mean gain of $50 \mathrm{~g}$ (Tables 1 and 2).

The research was carried out on 32 castrated, male, cross-bred Anglo-Nubian goats, with an average initial age of eight months, and a mean body weight of $18 \pm 2.5 \mathrm{~kg}$, which were weighed before the start of the experimental period after fasting for 16 hours, and were then distributed following a random block design across four treatments (supplementation levels) with eight replications (goats).

The research took 101 days, including 17 days of adaptation to experimental conditions and 84 days of data collection divided into four periods of 21 days. The goats were kept under continuous grazing in an experimental area of 37 hectares with a hyperxerophilic caatinga vegetation of dense trees and shrubs.

The pasture consisted of the following species, all potentially consumed by small ruminants. In the woody 
Table 1 - Bromatological composition of the supplement

\begin{tabular}{lccccc}
\hline \multicolumn{1}{c}{ Nutrient } & & \multicolumn{3}{c}{ Ingredient } \\
Palma miúda & Ground maize & Wheat bran & Soybean meal & Cottonseed \\
\hline Dry Matter (DM), \% & 14.26 & 88.48 & 86.59 & 89.55 & 91.31 \\
$\%$ DM & & & & & \\
Organic matter & 86.08 & 98.03 & 94.44 & 93.27 & 96.30 \\
Ash & 13.92 & 1.97 & 5.56 & 6.73 & 3.70 \\
Crude protein & 2.98 & 11.01 & 19.73 & 52.28 & 24.37 \\
Ether extract & 0.78 & 6.28 & 4.07 & 3.79 & 16.84 \\
Total carbohydratesa & 82.68 & 80.74 & 70.64 & 37.20 & 55.09 \\
Neutral detergent fibre corrected for ash & 18.4 & 22.74 & 40.67 & 21.72 & 49.35 \\
Acid detergent fibre & 8.84 & 2.67 & 11.76 & 6.52 & 11.76 \\
\hline
\end{tabular}

${ }^{\mathrm{a}}$ Calaculated as per Sniffen et al. (1992)

Table 2 - Centesimal and chemical composition of the supplement

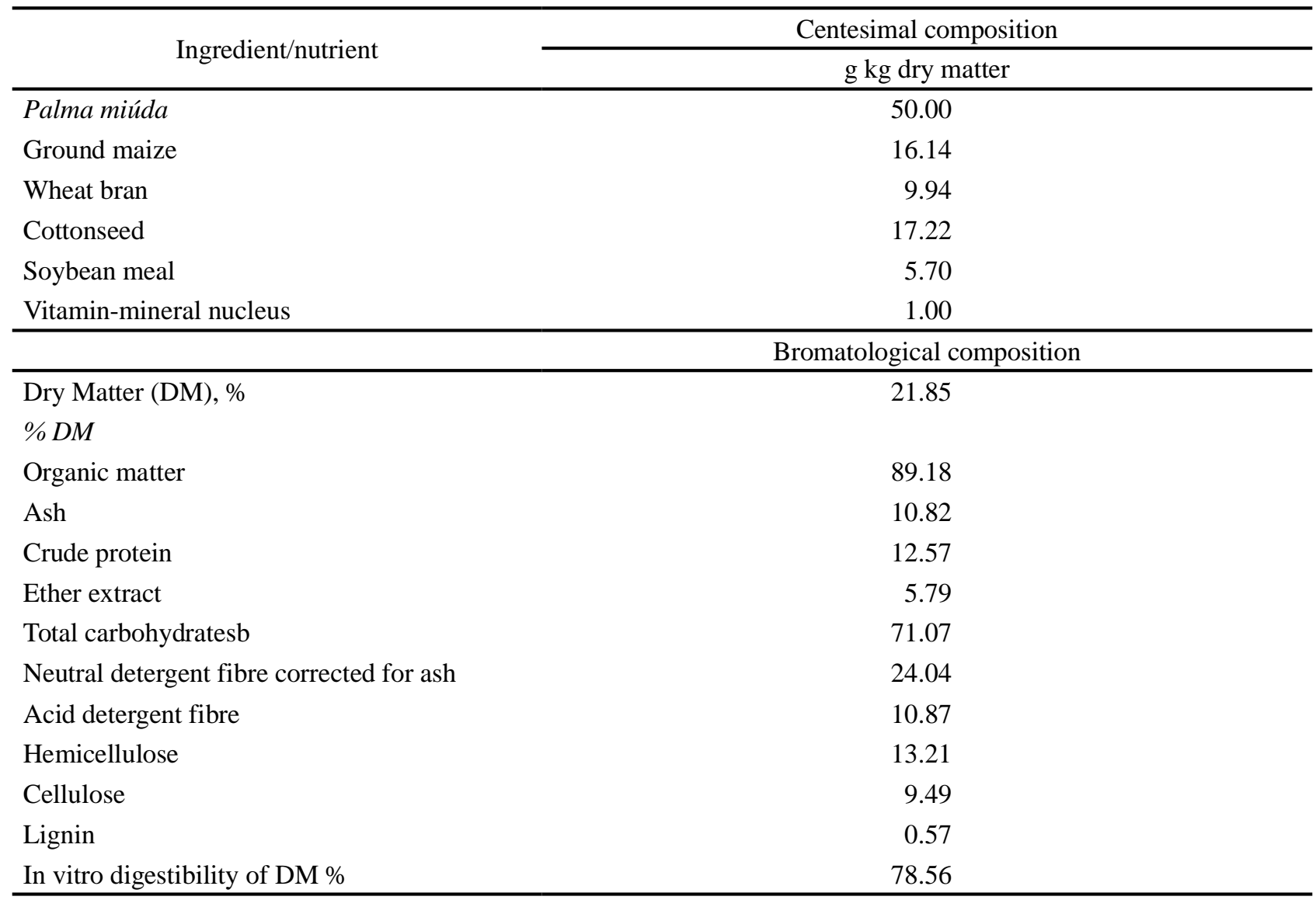

${ }^{\mathrm{a}}$ Caprinofós ${ }^{\circledast}$ (Tortuga, Brazil); ${ }^{\mathrm{b}}$ Calculated as per Sniffen et al. (1992)

strata: Astronium urundeuva Engl., Caesalpinia ferrea Mart., Caesalpinia pyramidalis Tul., Prosopis juliflora D. C., Spondias tuberosa Arruda Cam., Ziziphus joazeiro
Mart., Schinopsis brasiliensis Engl., and Bursera sp. In the shrub strata: Bauhinia cheillantha Steud., Calotropis procera Ait. R. Br., Capparis flexuosa L., Cordia 
leucocephala Moric., Croton sonderianus Muell. Arg., Croton sp., and Gomphrena vaga Mart. In the herbaceous strata, Boerhaavia coccinea Mill., Centrosema sp., Commelina obliqua Vahl., Desmanthus virgatus L. Willd., Diodia teres Walt., Ipomoea sp., Mimosa sp., Pavonia cancelata Cav., Selaginella convoluta Spring., Sida sp., and Tephrosia cinerea L. Pers.

The goats were allowed access to the pasture from 0700 to 1600 , when they were rounded up and taken to the experimental shed and housed in individual stalls where they received the feed supplement. Each stall was $1.0 \mathrm{x}$ 1.40 metres in size, covered, had a floor of beaten earth, and was equipped with a drinking trough, salt dispenser and feeder. It should be noted that the palma miúda was ground up just prior to feeding, and homogenized into the pre-mixture of energy-protein concentrates.

The animals were slaughtered at the end of the experimental period using a method of non-penetrative percussive concussion, followed by bleeding for four minutes, with a cut to the carotid and jugular, in compliance with Statute 3 of 17 January 2000 (Diário Oficial da União of 24/01/2000, Section 1, Page 14) (BRASIL, 2000). After slaughter, skinning and gutting, the head and feet were removed, leaving the carcass that was chilled for 24 hours at $4{ }^{\circ} \mathrm{C}$ in a cold storage chamber.

After this period, the carcasses were cut lengthwise and subdivided into six anatomical regions, as per Cezar e Sousa (2007). The left leg and loins were then stored at $-20{ }^{\circ} \mathrm{C}$, and dissected in an air-conditioned environment with the aid of a scalpel and tweezers into adipose tissue (subcutaneous and intermuscular), muscle, bone and other tissue types (connective tissue, tendons, glands, fasciae, nerves and vessels), according to Cezar e Souza (2007).

The chemical composition was determined at the Laboratory of Animal Nutrition of the Department of Animal Science at the Federal Rural University of Pernambuco (UFRPE), where for the pre-drying process, samples of the semimembranosus muscle were removed from the right leg, ground in a domestic blender, and then lyophilized for 48 hours. The samples were pre-defatted, and levels were then determined for final moisture, crude protein, ether extract and ash, as per AOAC (2000).

At the same time, at the Food Laboratory of the Department for Domestic Science of UFRPE, chromatic characterisation was carried out on samples of the longissimus lumborum muscle, removed from the right leg after the muscle surface had been exposed to the air for 30 minutes in an environment cooled to $5{ }^{\circ} \mathrm{C}$, so as to allow surface oxygenation of the myoglobin. Three readings were taken at different locations on the muscle with a colorimeter (KONICA MINOLTA CR-400 Colour Meter) using the CIELAB ( $\left.\mathrm{L}^{*}, \mathrm{a}^{*}, \mathrm{~b}^{*}\right)$ system, where $\mathrm{L}^{*}$ is lightness, and ranges from black $(0 \%)$ to white $(100 \%)$; $\mathrm{a}^{*}$ is the intensity of the colour red, which varies from green (-a) to red (+a); and $b^{*}$ the intensity of yellow, ranging from blue (-b) to yellow (+b), as per CIE methodology (1978).

Determination of the $\mathrm{pH}$ was carried out on aliquots of $5 \mathrm{~g}$ of the longissimus lumborum muscle homogenised in $100 \mathrm{~mL}$ of deionized water, from readings taken with a digital potentiometer (TECNAL, model pHmetro Tec3MP).

Cooking loss and shear force were evaluated at the Food Laboratory of the Department for Domestic Science of UFRPE, in samples of the longissimus lumborum muscle cooked in an oven preheated to $200{ }^{\circ} \mathrm{C}$ until the internal temperature of the meat reached $75^{\circ} \mathrm{C}$, when cooking loss was calculated as the difference in the weight of the samples before and after cooking, and expressed as a percentage. Shear force was determined by adopting the Warner-Bratzler Shear Force (WBSF) analysis protocol, (SALTER, model 235 6X), as per Ramos e Gomide (2007).

The sensory-attribute characteristics of goat aroma, off-aroma, colour, texture, tenderness, characteristic goat flavour, off-flavour, juiciness and overall appearance were evaluated at the Food Laboratory of the Department for Domestic Science of UFRPE by Qualitative Descriptive Analysis (QDA), on an unstructured $9 \mathrm{~cm}$ scale, where the attribute intensities ranged from 1 (lowest) to 9 (highest), as described by Monte et al. (2007).

The sensory panel consisted of nine trained tasters from the group of tasters of the Department for Domestic Science of UFRPE, which were selected from among 30 people, taking into consideration at the initial screening: affinity to the product, availability, interest to participate in the tests, and other parameters related to health and eating habits. Applicants were also evaluated as to their sensitivity to such tastes as sour, bitter, sweet and umami.

Training for members of the panel consisted of three open sessions (60 $\mathrm{min} / \mathrm{session})$, where samples of goat meat obtained commercially were evaluated and the terms of reference adopted in the QDA defined consensually, with the attributes described in Table 3 also being standardised.

After training, a pilot test was held using samples of goat meat, where the tasters demonstrated a satisfactory ability to discriminate between samples $(\mathrm{p}<0.35)$ and reproduce their assessments $(\mathrm{p}>0.05)$.

The samples used in the sensory evaluation were from the longissimus lumborum, removed from the left loin. These were wrapped in aluminium foil and roasted in a preheated oven at $200{ }^{\circ} \mathrm{C}$ until the internal temperature 
Table 3 - Attributes used for sensory evaluation

\begin{tabular}{|c|c|}
\hline Attribute & Description \\
\hline \multicolumn{2}{|l|}{ Goat aroma } \\
\hline - Characteristic & Typical goat-meat smell \\
\hline - Bad & Non-characteristic odour \\
\hline \multicolumn{2}{|l|}{ Colour } \\
\hline - Dark & Characteristic colour of older animals \\
\hline - Light & Characteristic colour of younger animals \\
\hline Texture & $\begin{array}{l}\text { Rheological and structural properties of the meat perceptible to mechanical and tactile } \\
\text { receptors }\end{array}$ \\
\hline Tenderness & Resistance properties of the meat to initial bite \\
\hline \multicolumn{2}{|l|}{ Flavour } \\
\hline - Characteristic & Typical goat-meat flavour \\
\hline - Bad & Flavour not characteristic of goat meat \\
\hline Juiciness & $\begin{array}{c}\text { A property of texture, as related to the perceived quality of the moisture absorbed or released } \\
\text { by the meat }\end{array}$ \\
\hline \multicolumn{2}{|c|}{ Overall appearance } \\
\hline - Good & $\begin{array}{l}\text { Visible properties of the meat such as colour, shape and the characteristic brightness of the } \\
\text { goat meat }\end{array}$ \\
\hline - Bad & Disagreeable appearance, such as atypical colour and a hard, dry, firm texture \\
\hline
\end{tabular}

Source: DIAS et al. (2008)

of the samples reached $75{ }^{\circ} \mathrm{C}$. After this process, they were divided into $2.5 \mathrm{~cm}$ cubes, giving $15 \mathrm{~g}$ samples, which were then transferred to preheated beakers, encoded and covered with aluminium foil to prevent the loss of volatiles. The beakers were kept warm $\left(65\right.$ to $\left.75^{\circ} \mathrm{C}\right)$ until the samples were distributed to the tasters on the sensory panel.

Prepared samples of goat meat were offered, served on disposable white polyethylene plates and forks, to each taster in individual booths. Mineral water at room temperature and unsalted crackers were used to remove any residual flavour between the samples of each treatment. The samples were offered in a randomised pattern, so that each sample was tested three times by each taster, alternating between treatments.

The forms for evaluating the attributes were made available to each taster together with the samples, with directions to mark the point on the scale that best reflected their judgment of the intensity of the attribute after tasting each sample, and to register the sample code on the form. All the data were later transformed into scores, which ranged from 1 to 9 .

A randomised block design was adopted, of four treatments (levels of supplementation), eight replications (goats) and four blocks (live weight). The data were analysed with the PROC MEANS procedure of the SAS (2001) statistical software, using descriptive statistics for the mean, standard deviation and coefficient of variation; the PROC GLM procedure was used for regression analysis, and PROC CORR for correlation.

\section{RESULTS AND DISCUSSION}

The performance parameter, final body weight $(\mathrm{FBW})$, was influenced $(\mathrm{p}<0.05)$ by the feed supplementation, resulting in a positive linear effect $(p<0.05)$, with an increase of $2.6 \mathrm{~kg}$ per percentage point of supplementation (Table 4).

The parameters for the chemical composition of the longissimus lumborum loin muscle in goats were influenced $(\mathrm{p}<0.05)$ by the levels of supplementation (Table 4$)$, and resulted in a quadratic effect $(\mathrm{p}<0.05)$ on the ash and protein content, with a maximum of 1.06 and $20.44 \mathrm{~g} / 100 \mathrm{~g}$, when using 0.75 and $0.91 \% \mathrm{BW}$ of feed supplementation respectively, and a positive linear effect $(\mathrm{p}<0.05)$ on the fat content, with an increase of $0.52 \mathrm{~g} / 100 \mathrm{~g}$ per percentage point of supplementation. An exception was noted for moisture content, which was not affected ( $>0.05)$, having a mean value of $79.53 \mathrm{~g} / 100 \mathrm{~g}$. 
This lack of effect on moisture content can be attributed to the parameter being less influenced by the nutritional profile and more influenced by age at slaughter, as noted by Beserra et al. (2004) in Moxotó and crossbred goats, which displayed a lower moisture content for older animals.

The mean values, found for chemical composition of the meat from goats submitted to the lowest and highest levels of feed supplementation, agree with those obtained by Madruga et al. (2009) for meat of $1 / 2$ Anglo-Nubian $x 1 / 2$ SPRD crossbred goats finished on a feedlot and slaughtered at $29.0 \pm 2.0 \mathrm{~kg}$, with $72.79 \pm 1.14 \mathrm{~g} / 100 \mathrm{~g}$ for moisture, $0.99 \pm 0.08 \mathrm{~g} / 100 \mathrm{~g}$ for ash, and $24.18 \pm 1.02$ $\mathrm{g} / 100 \mathrm{~g}$ for protein. An exception was seen for fat content, $2.44 \pm 0.77 \mathrm{~g} / 100 \mathrm{~g}$, which was higher than that obtained in this study (Table 4), and was attributed to the goats here having been largely finished on a pasture of caatinga, resulting in considerable movement, thereby reducing the deposition of muscular fat.

The above results demonstrate the benefits of feed supplementation when finishing goats on a pasture of caatinga, since the values for the chemical composition of the longissimus lumborum muscle were close to results obtained for goats finished on a feedlot, confirming that correcting for limiting nutrients by feed supplementation is a prerequisite for a satisfactory performance on caatinga pasture.

According to Monte et al. (2012) the chemical composition of goat meat may be influenced by such factors as breed, crossbreeding, age and sex. However, it can be seen that the nutritional aspect may also be considered an influencing factor, because in general feed supplementation caused an increase in the concentration of nutrients in the meat, reflecting in a product of improved nutritional quality.

Proteins in meat originate mainly in the muscle and connective tissues. For muscle tissue the amount of crude protein varies from 18 to $22 \mathrm{~g} / 100 \mathrm{~g}$, with myofibrillar protein being present in greater quantities, followed by sarcoplasmic protein (MONTE et al., 2012). From these values it can be inferred that supplementation resulted in meat that was within the set range, increasing to a maximum of $20.44 \mathrm{~g} / 100 \mathrm{~g}$ when using feed supplementation at $0.91 \%$ BW (Table 4).

The decrease in protein content with the use of higher levels of feed supplementation is considered a normal result, as in the physiology of muscular development there is a threshold above which cells show no increase in muscle deposition, and consequently in the deposition of myofibrillar protein. This is considered to be a mechanism for protecting the muscle against excessive deposition.

The qualitative parameters of the goat meat were influenced $(p<0.05)$ by the levels of feed supplementation (Table 5), resulting in a negative linear effect $(\mathrm{p}<0.05)$ on cooking loss, shear force and luminosity $\left(\mathrm{L}^{*}\right)$, with a decrease of $3.32 \%, 0.77$ kgf and 3.39 respectively per percentage point of supplementation, and a quadratic effect $(\mathrm{p}<0.05)$ on the intensity of the colour red $\left(\mathrm{a}^{*}\right)$, with a maximum of 9.13 when using a level of feed supplementation of $0.94 \%$ BW. The intensity of yellow (b*) showed a quadratic effect $(\mathrm{p}<0.05)$, with a maximum of 8.12 when feed supplementation was offered at $0.67 \% \mathrm{BW}$.

The $\mathrm{pH}$ value of the meat was not affected $(\mathrm{p}>0.05)$ by feed supplementation, having a mean value of 5.57 . According to Ramos e Gomide (2007), pH is the most influential factor for the quality and safety of food. In meat, $\mathrm{pH}$ is related to the post-mortem accumulation of lactic acid, where the amount and rate of accumulation influences the final quality of the meat.

In such a situation, evaluation of the $\mathrm{pH}$ does not allow characterisation of the biochemical changes in the muscle during rigor mortis, since the measurement was

Table 4 - Mean values and regression equations for final body weight (FBW) and chemical composition of the longissimus lumborum loin muscles in crossbred goats finished on a pasture of caatinga and receiving feed supplementation

\begin{tabular}{|c|c|c|c|c|c|c|}
\hline \multirow{2}{*}{ Parameter } & \multicolumn{4}{|c|}{ Level of feed supplementation (\% BW) } & \multirow{2}{*}{ Regression equation } & \multirow{2}{*}{ SEM* } \\
\hline & 0.0 & 0.4 & 0.8 & 1.2 & & \\
\hline FBW (kg) & 18.93 & 19.50 & 20.11 & 22.19 & 1 & 0.532 \\
\hline Moisture (g/100 g) & 80.17 & 81.37 & 78.21 & 78.38 & $\hat{\mathrm{Y}}=79.53$ & 0.745 \\
\hline Ash (g/100 g) & 0.99 & 1.05 & 1.06 & 1.04 & 2 & 0.009 \\
\hline Fat $(\mathrm{g} / 100 \mathrm{~g})$ & 1.02 & 1.24 & 1.49 & 1.63 & 3 & 0.084 \\
\hline Protein $(g / 100 g)$ & 17.66 & 19.59 & 20.38 & 20.18 & 4 & 0.265 \\
\hline
\end{tabular}

*SEM $=$ Standard error of the mean; ${ }^{1} \hat{y}=18.6241+2.5961 x ; R^{2}=0.70 ; p<0.02 ;{ }^{2} \hat{y}=0.99+0.18 x-0.12 x^{2} ; R^{2}=0.37 ; p<0.03 ;{ }^{3} \hat{y}=1.03+$ $0.52 \mathrm{x} ; \mathrm{R}^{2}=0.43 ; \mathrm{p}<0.003 ;{ }^{4} \hat{\mathrm{y}}=17.67+6.02 \mathrm{x}-3.32 \mathrm{x}^{2} ; \mathrm{R}^{2}=0.66 . \mathrm{p}<0.004$ 
Table 5 - Mean values and regression equations for the qualitative aspects of the longissimus lumborum loin muscle in crossbred goats finished on a pasture of caatinga and receiving feed supplementation

\begin{tabular}{|c|c|c|c|c|c|c|}
\hline \multirow{2}{*}{ Parameter } & \multicolumn{4}{|c|}{ Level of feed supplementation (\% BW) } & \multirow{2}{*}{ Regression equation } & \multirow{2}{*}{ SEM* } \\
\hline & 0.0 & 0.4 & 0.8 & 1.2 & & \\
\hline $\mathrm{L}^{*}$ & 44.21 & 42.30 & 40.33 & 40.45 & 1 & 0.568 \\
\hline$a^{*}$ & 7.79 & 8.63 & 9.15 & 9.00 & 2 & 0.196 \\
\hline$b^{*}$ & 7.24 & 7.78 & 8.28 & 7.45 & 3 & 0.160 \\
\hline $\mathrm{pH}$ & 5.50 & 5.40 & 5.83 & 5.55 & $\hat{\mathrm{Y}}=5.57$ & 0.085 \\
\hline Cooking loss $(\%)$ & 43.62 & 43.26 & 38.86 & 40.66 & 4 & 0.696 \\
\hline Shear force $\left(\mathrm{gf} / \mathrm{cm}^{2}\right)$ & 4.19 & 3.52 & 3.35 & 3.25 & 5 & 0.155 \\
\hline
\end{tabular}

${ }^{*} \mathrm{SEM}=$ Standard error of the mean; ${ }^{1} \hat{\mathrm{y}}=43.83-3.39 \mathrm{x} ; \mathrm{R}^{2}=0.42 ; \mathrm{p}<0.006 ;{ }^{2} \hat{\mathrm{y}}=7.77+2.90 \mathrm{x}-1.55 \mathrm{x}^{2} ; \mathrm{R}^{2}=0.28 ; \mathrm{p}<0.01 ;{ }^{3} \hat{\mathrm{y}}=7.18+2.82 \mathrm{x}-2.11 \mathrm{x}^{2}$; $R^{2}=0.22 ; p<0.03 ;{ }^{4} \hat{y}=43.59-3.32 x ; R^{2}=0.35 ; p<0.02 ;{ }^{5} \hat{y}=4.04-0.77 x ; R^{2}=0.40 ; p<0.02$

taken in the muscle sample after a period of storage. However, it becomes an important variable at the time the meat is consumed. The mean value for the $\mathrm{pH}$ in this research of 5.6, is within the range proposed by Madruga et al. (2008) for meat from Moxotó and Caninde goats, and considered to be within normal range.

According to Ramos e Gomide (2007), classifying the meat according to final quality is achieved more efficiently when the $\mathrm{pH}$ is used together with the measurements for $\mathrm{L}^{*}$. In this case, as the $\mathrm{pH}$ remained uniform, the decrease of 3.39 in the $\mathrm{L}^{*}$ parameter as a function of feed supplementation levels can be explained by a possible increase in the levels of myoglobin in the muscle. These results are corroborated by the maximum of 9.13 for the $a^{*}$ parameter, which showed a negative correlation, $r=-0.62(p<0.05)$, with the $L^{*}$ parameter, indicating that the meat became a reddish pink, reducing the reflection of light. According to Ramos e Gomide (2007), the increase in the pinkish colour of goat meat at higher concentrations of myoglobin is related to the iron ion content of the tissue.

Assessing the effect of including coarse wheat bran in the diet of crossbred male goats, aged 6-7 months and finished on a feedlot, Dias et al. (2008) reported lower ranges for $\mathrm{L}^{*}$ and $\mathrm{b}^{*}$ than those obtained in this study, 30.2 to 32.4 and 5.01 to 6.37 respectively, similarly for a*, from 7.56 to 8.47 , indicating that the meat obtained here was lighter in colour, demonstrated by the greater value for $\mathrm{L}^{*}$, with hue ranging from light pink to yellow, shown by the greater value for $b^{*}$.

The increase in the $b^{*}$ parameter when providing feed supplementation at $0.67 \% \mathrm{BW}$, is directly related to the increase in the fat content of the meat, which was confirmed by the positive correlation $(r=0.45, \mathrm{p}<0.05)$ between the parameters, indicating that the meat acquired a yellowish colouring.
Generally, consumers of goat meat prefer meat of a bright red colour, rejecting those of a darker and duller colour, as they associate the dark colour with having come from an older animal (DIAS et al., 2008).

There was a decrease of $3.32 \%$ in cooking loss as a function of the level of feed supplementation, demonstrating the beneficial effect of this feeding management on meat quality, as it gives the consumer greater yield when cooking. Mean values for cooking loss were higher than those obtained by Dias et al. (2008), 20.7 to $29.2 \%$, but considerably lower than those found by Ding et al. (2010) in Boer x Guanzhong crossbred goats in China, 60.95 to $61.93 \%$.

In this research, values for cooking loss did not correlate with $\mathrm{pH}$, indicating no relationship between the high values and such abnormal conditions as pale soft exudative meat. In this case, the result can be explained by the influence of freezing on the samples, where storage at temperatures between -10 and $-18^{\circ} \mathrm{C}$, common in domestic freezing, promotes, according to Lagerstedt et al. (2008), the formation of ice crystals in the inter- and intracellular spaces, leading to destruction of the muscle cell structure and a consequent discharge of liquid.

The rheological evaluation of shear strength showed a decrease in the toughness of the meat of the order of $0.77 \mathrm{kgf}$ per percentage point of supplementation (Table 5), and can be considered as beneficial.

Consumer response to meat tenderness can vary greatly, due to a number of combined effects caused by differences in the method and amount of cooking, and to variations in the threshold for acceptability from consumer to consumer. In general, there is a consensus that the threshold for tough meat is $4.6 \mathrm{kgf}$, which allows meat from the animals in this research to be classified as tender. 
As for the sensory attributes of the longissimus lumborum muscle, feed supplementation did not affect ( $>0.05)$ the parameters of goat aroma, off-aroma, texture, tenderness, flavour, off-flavour and juiciness, which had mean scores of 2.26, 0.1, 3.26, 3.15, 2.79, 0.14 , and 3.38 respectively. The parameters of colour and overall appearance were influenced $(\mathrm{p}<0.05)$ by the level of feed supplementation, which resulted in a positive linear effect $(p<0.05)$, with increases of 0.92 and 0.45 percentage points per added level of feed supplementation (Table 6).

In general, the mean values allocated to the parameters evaluated by the judges can be considered as satisfactory, seeing as how the most desirable attributes were close to the mean on the scale of 1 to 9 used in the evaluation. It's important to note that the parameters of off-aroma and off-flavour received the lowest scores from the sensory panel, 0.1 and 0.14 respectively (Table 6), indicating that feed supplementation did not determine the occurrence of off-flavour in the samples evaluated, which is a beneficial result for the consumer.

The attribute, goat aroma, had mean values below the mean on the scale used in the evaluation (Figure 1), which represents a beneficial result, since a very pronounced goat aroma is considered undesirable by some consumers. The low intensity of this attribute may be related to the young age of the animals, and to the fact they were castrated before the start of the experiment.

As can be seen in Figure 1, the parameter, colour, showed a variation which depended on the levels of feed supplementation, with a linear increase of 0.92 points as a function of this level, following the trend seen for parameter $\mathrm{a}^{*}$ in the evaluations employing CIELAB (Table 5), and confirming the data for the mean values given by the judges. The increase in the pink hue of the meat is related to the higher nutrient intake available for muscle development from the feed supplementation, which resulted in a greater production of haemoglobin and myoglobin.

Figure 1 - Sensory attributes of goat meat for different levels of feed supplementation (\% BW)

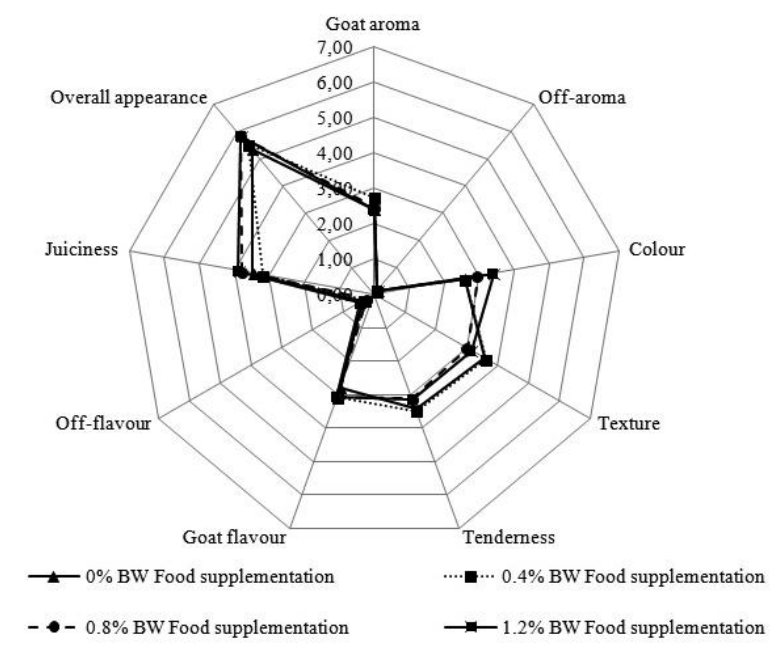

Despite the variation seen in Figure 1, the judges could perceive no changes to the parameter, meat texture, for feed supplementation, unlike shear force, which decreased $0.77 \mathrm{kgf} / \mathrm{cm}^{2}$ (Table 5) with increases

Table 6 - Mean values and regression equations for the sensory evaluation of the longissimus lumborum loin muscle in crossbred goats finished on a pasture of caatinga and receiving feed supplementation

\begin{tabular}{|c|c|c|c|c|c|c|}
\hline \multirow{2}{*}{ Parameter } & \multicolumn{4}{|c|}{ Level of feed supplementation (\%BW) } & \multirow{2}{*}{$\begin{array}{l}\text { Regression } \\
\text { equation }\end{array}$} & \multirow{2}{*}{ SEM $*$} \\
\hline & 0.0 & 0.4 & 0.8 & 1.2 & & \\
\hline Goat aroma & 2.09 & 2.33 & 2.18 & 2.04 & $\hat{Y}=2.26$ & 0.157 \\
\hline Off-aroma & 0.09 & 0.10 & 0.11 & 0.10 & $\hat{\mathrm{Y}}=0.1$ & 0.004 \\
\hline Colour & 2.38 & 2.38 & 2.95 & 3.41 & 1 & 0.131 \\
\hline Texture & 3.58 & 3.29 & 3.01 & 3.15 & $\hat{Y}=3.26$ & 0.139 \\
\hline Tenderness & 3.44 & 3.11 & 2.90 & 3.15 & $\hat{Y}=3.15$ & 0.145 \\
\hline Flavour & 2.55 & 2.76 & 3.05 & 2.80 & $\hat{Y}=2.79$ & 0.176 \\
\hline Off-flavour & 0.15 & 0.12 & 0.13 & 0.15 & $\hat{Y}=0.14$ & 0.017 \\
\hline Juiciness & 3.23 & 3.19 & 3.52 & 3.59 & $\hat{Y}=3.38$ & 0.149 \\
\hline Overall appearance & 5.35 & 5.52 & 5.84 & 5.84 & 2 & 0.243 \\
\hline
\end{tabular}

${ }^{*} \mathrm{SEM}=$ Standard error of the mean; ${ }^{1} \hat{y}=2.23+0.92 \mathrm{x} ; \mathrm{R}^{2}=0.66 ; \mathrm{p}<0.008 ;{ }^{2} \hat{\mathrm{y}}=5.37+0.45 \mathrm{x} ; \mathrm{R}^{2}=0.91 ; \mathrm{p}<0.05$ 
in the levels of supplementation, but was also not noticeable to the discriminating powers of the judges.

Dias et al. (2008) emphasize that the concentration of fat on the carcass is directly related to the tenderness of the meat, with intramuscular fat being mainly responsible for increases in this parameter, while subcutaneous fat acts as insulation, preventing the sudden cooling of the carcass that produces shortening of the sarcomeres and promotes greater toughness of the meat.

In this study therefore, the lack of effect from feed supplementation on the parameter, tenderness, may be related to the choice of the longissimus lumborum muscle for the sensory evaluation, which, coming from crossbred animals that have the undefined breed genotype together with components of native breeds that tend to show reduced deposition of intramuscular and subcutaneous fat, resulted in similarities between the scores assigned to this parameter.

The lack of effect on the parameter, juiciness, (Table 6) may be directly related to an absence of variation in texture and tenderness (Figure 1), since tender and softer meats tend to show a greater release of cellular and interstitial fluids, increasing juiciness. This effect is further confirmed by the lack of correlation $(p>0.05)$ between these parameters.

Borges et al. (2006), when evaluating instrumental and sensory measurements of toughness and juiciness in goat meat, found a negative correlation between sensory juiciness and shear force $(\mathrm{r}=-0.35, \mathrm{p}<0.05)$, and sensory juiciness and toughness $(r=-0.75, p<0.01)$.

The attribute, overall appearance, received the greatest mean values compared to the other attributes assessed by the judges (Figure 1), allowing the overall appearance of the meat to be rated as satisfactory, since it corresponded to over half of the rating scale.

\section{CONCLUSIONS}

1. Feed supplementation at $0.8 \% \mathrm{BW}$ results in meat of better nutritional quality, with high levels of ash, fat and protein, together with qualitative improvements in cooking loss, tenderness and colour;

2. The use of feed supplementation does not alter the sensory attributes of goat meat. However, the colour and overall appearance of the meat benefit from this feeding strategy, making it more appropriate for the standards of consumers.

\section{REFERENCES}

ANDRADE, A. P. et al. Produção animal no semiárido: o desafio de disponibilizar forragem, em quantidade e com qualidade, na estação seca. Tecnologia e Ciência Agropecuária, v. 4, n. 4, p. 1-4, 2010.

ASSOCIATION OF OFFICIAL ANALITICAL CHEMISTS. Officinal methods of analysis. $19^{\text {th }}$ ed., Washington, D.C., 2000. 1210 p.

BESERRA, F. J. et al. Effect of age at slaughter on chemical composition of meat from Moxotó goats and their crosses. Small Ruminant Research, v. 55, n. 1/3, p. 177-181, 2004.

BORGES, A. S. et al. Medições instrumentais e sensoriais de dureza e suculência na carne caprina. Ciência e Tecnologia de Alimentos, v. 25, n. 4, p. 891-896, 2006.

BRASIL. Ministério da Agricultura. Instrução Normativa $\mathbf{n}^{\circ}$. 3, de 07 de janeiro de 2000. Regulamento técnico de métodos de insensibilização para o abate humanitário de animais de açougue. S.D.A./M.A.A. Brasília, 2000. Disponível em: <http:// extranet.agricultura.gov.br/ sislegis/ action/detalhaAto.do?meth od=consultarLegislacaoFederal $>$ Acesso em: 1 jun. 2010.

CEZAR, M. F.; SOUSA, W. H. Carcaças ovinas e caprinas: obtenção, avaliação e classificação. Uberaba: Editora Agropecuária Tropical, 2007. 147 p.

COMISSION INTERNATIONALE DE I' ECLAIRAGE. Recommendations on uniform color spaces-color difference equations, psychomettic color terms. Paris: CIE, 1978. Supplement n. 2 to CIE Publication n. 15.

DIAS, A. M. A. et al. Inclusão do farelo grosso de trigo na dieta e seu efeito sobre as propriedades físicas e sensoriais da carne caprina. Ciência e Tecnologia de Alimentos, v. 28, n. 3 , p. $527-533,2008$

DING, W. et al. Meat quality parameters of descendants by grading hybridization of Boer goat and Guanzhong Dairy goat. Meat Science, v. 84, n. 3, p .323-328, 2010.

INSTITUTO BRASILEIRO DE GEOGRAFIA E ESTATÍSTICA. Pesquisa Pecuária Municipal, v. 39, p. 163, 2011. Disponível em: <ftp://ftp.ibge.gov.br/Producao_ Pecuaria/ Producao_da_Pecuaria_Municipal/2011/ppm 2011. pdf>. Acesso em: 12 nov. 2013.

LABORATÓRIO DE METEOROLOGIA DE PERNAMBUCO. Climatologia. Disponível em: 〈http://itep.br/LAMEPE.asp>. Acesso em: 20 jul. 2011.

LAGERSTEDT, Å. et al. Effect of freezing on sensory quality, shear force and water loss in beef $M$. longissius dorsi. Meat Science, v. 80, n. 2, p. 457-461, 2008.

MADRUGA, M. S. et al. Chemical composition and fat profile of meat from crossbred goats reared under feedlot systems. Revista Brasileira de Zootecnia, v. 38, n. 3, p. 547-552, 2009.

MADRUGA, M. S. et al. Meat quality of Moxotó and Canindé goats as affected by two levels of feeding. Meat Science, v. 80, n. 4, p. 1019-1023, 2008. 
MADRUGA, M. S. et al. Qualidade da carne de cordeiros Santa Inês terminados com diferentes dietas. Revista Brasileira de Zootecnia, v. 34, n. 1, p. 309-315, 2005.

MONTE, A. L. S et al. Parâmetros físicos e sensoriais de qualidade da carne de cabritos mestiços de diferentes grupos genéticos. Ciência e Tecnologia de Alimentos. v. 27, n. 2, p. 233-238, 2007.

MONTE, A. L. S. et al. Qualidade da carne de caprinos e ovinos: uma revisão. Agropecuária Científica no SemiÁrido, v. 8, n. 3, p. 11-17, 2012.

NATIONAL RESEARCH COUNCIL. Nutrient requirements of small ruminants: sheep, goats, cervids, and new world camelids. Washington, D.C.: National Academy Press, 2007. $362 \mathrm{p}$.

PAULINO, M. F. et al. Uso da suplementação: como, quando e por quê?. In: MUNIZ, Evandro Neves. Alternativas alimentares para ruminantes. 2. ed. Embrapa, 2008. p. 81123.2008 .

RAMOS, E. M.; GOMIDE, L. A. M. Avaliação da qualidade de carnes: fundamentos e metodologias. Viçosa: Ed. UFV, 2007. $599 \mathrm{p}$.

SANTOS FILHO, J. M. et al. Effect of cashew nut supplemented diet, castration and time storage on fatty acid composition and cholesterol content of goat meat. Small Ruminant Research, v. 57, n. 1, p. 51-56, 2005.

SNIFFEN, C. J. et al. A net carbohydrate and protein system for evaluating cattle diets: II Carbohydrate and protein availability. Journal Animal Science, v. 70, n. 11, p. 35623577, 1992.

SAS INSTITUTE. Statistical Analysis System. SAS/STAT User's Guide. Cary, NC: SAS Institute, 2001. 